\title{
English for Medical Purposes for Saudi Medical and Health Professionals
}

\author{
Fahad Alqurashi \\ Department of English, Umm Al-Qura University, Makkah, Saudi Arabia \\ Email: fmqurashi@uqu.edu.sa
}

Doi:10.7575/aiac.alls.v.7n.6p.243

URL: http://dx.doi.org/10.7575/aiac.alls.v.7n.6p.243
Received: 16/10/2016

Accepted: 20/11/2016

\begin{abstract}
This study explored the English language needs of 156 Saudi fellowship doctors and students of medical majors who are enrolled at medical and training programs in Australian hospitals and universities. Data were collected via a questionnaire adopted from a previous study. Participants' responses showed the most frequently used language subskills were those sub-skills they considered highly important. Results emphasize the findings of previous studies that learners usually attach high importance to any skills that they use frequently to help them achieve the utmost aim of improving their language abilities. In addition, the study findings suggest current college English language courses for medical majors need to focus more on improving language-related aspects like fluency, understanding, accuracy, and structure. Such changes are necessary to prepare doctors and medical professionals for work in medical jobs that depend on heavy usage of the English language and also improving communicative competence aspects to ensure smooth cultural interaction with co-workers from all around the world. The study concludes by pointing that there is a critical need to restructure English for medical purposes programs in Saudi Arabia to make better course design, content, and materials responsive to target language learners' own future goals.
\end{abstract}

Keywords: Saudi; English language skills; Needs analysis (NA); English for specific purposes (ESP); English for medical purposes (EMP)

\section{Introduction}

English language has achieved a paramount global status, developed a special role that is well-recognized in the world, and has become a vital part of the international society, culture and the economy (Gatehouse, 2001). Knowing English has become a key requirement to succeed as a specialist in any profession or field of knowledge. English makes a significant contribution to sustainable global development by facilitating communications between countries that do not share a common language (Robson, 2014). In addition, English has globally become the primary means of international communications in business, education, and the common language of international experts in a wide range of subjects, such as medicine, the natural sciences and the social sciences (Hutchinson and Waters, 1992). Consequently, the language teaching profession has seen the emergence of language teaching for specific purposes.

Since 1960s, English for Specific Purposes (ESP) has gained increasing significance in language education and became a well-recognized movement within the field of English Language Teaching (ELT) (Lili, 2015). More and more people are utilizing English for everyday purposes in multiple occupational, professional, and academic contexts which places further demands on ELT professionals and institutions to design and deliver ESP courses to target specific professional activities and academic programs. According to Robinson (1991), there are two absolute criteria for defining such activities and programs. They are normally goal-oriented and derive from a needs analysis process that states clearly what the learners will have to do when speaking the language. Researchers emphasized the role of learners' individual needs and specialist knowledge of using English for specific purposes and considered them more important than any concrete limits of students' level or age (Hutchinson \& Waters, 1992).

Researchers provided multiple definitions and characteristics for the educational setting/process that involve a particular group of students learning English for specific fields or a professional career. For example, Hutchinson and Waters (1992) theorize, "ESP is an approach to language teaching in which all decisions as to content and method are based on the learner's reason for learning" (19). A later definition introduces ESP as "the branch of English language education which focuses on training in specific domains of English to accomplish specific academic or workplace tasks" (Orr, 2005: 9). In addition, Dudley-Evans (1997) defined ESP in terms of its absolute and variable characteristics:

\section{Absolute Characteristics}

1. ESP is defined to meet specific needs of the learners

2. ESP makes use of underlying methodology and activities of the discipline it serves

3. ESP is centered on the language appropriate to these activities in terms of grammar, lexis, register, study skills, discourse and genre. 
Variable Characteristics

1. ESP may be related to or designed for specific disciplines

2. ESP may use, in specific teaching situations, a different methodology from that of General English

3. ESP is likely to be designed for adult learners, either at a tertiary level institution or in a professional work situation.

It could, however, be for learners at secondary school level

4. ESP is generally designed for intermediate or advanced students.

5. Most ESP courses assume some basic knowledge of the language systems

The sub-field of English for medical purposes (EMP) has emerged out of the field of English for Specific Purposes to meet the specific academic and professional needs of learners of medicine and medicine-related specializations. Learning English for medical purposes focuses on the unique type of vocabulary and language skills that medical practitioners are likely to require in work place to meet specific demands to communicate in English with certain groups of people about fairly specific topics (Antic, 2007). Recently, English for medical purposes has developed its own research base, disciplinary content, and pedagogy. English for medical purposes involves the selection of authentic and interesting readings that are relevant to the medical field and at the right level for students (Skelton \& Whetstone, 2012). In addition, various medicine-related activities and materials that highlight specific rhetorical and discourse features should be provided to serve as a scaffold that builds on students' existing language and content knowledge in order to facilitate comprehension of the specialized texts (Porcaro, 2013).

\section{EMP in Saudi Arabia}

Students of medicine and medicine-related sciences in Saudi Arabia spend 5-6 years in school studying in English. In most Saudi universities, students start with the preparatory year in which they take intensive English courses in addition to pre-medical requirements and basic sciences like Biology, Chemistry and Physics. Then, students are enrolled in schools of medicine, dentistry, nursing, or health sciences based on their GPA in the preparatory year where they continue to study in English (Kaliyadan et al, 2015). However, Previous studies reported that curriculum in medical schools in Saudi Arabia is almost totally problem-based with only few sessions delivered as interactive lectures (AlKabbaa et al., 2012). Other studies found that medical schools in Saudi Arabia are a traditional educational environment where the curriculum is teacher-centred, discipline-based and hospital-based with no options or elective modules. Teaching methods include lectures and tutorials where the teacher is still the main source of information while practical classes and problem-based sessions are limited (Al-Hazimi et al., 2004).

Many students who graduate from medical schools in Saudi Arabia had the opportunity to pursue graduate studies abroad. Universities, hospitals, and, recently, King Abdullah Scholarship Program sent students to foreign countries to study master, doctoral, and fellowship programs in all the medical fields (Taylor \& Albasri, 2014). Many Saudi fellowship doctors and graduate students joined medical/training programs in Australian hospitals and universities in the last decade. Saudi students, along with the vast majority of international students, experience a range of learning difficulties that affect their overall educational progress (Amed, 2011; Barron, 2004). Studying in a language that is not their first language made most international students spend time to adjust to the Australian accent and the style of speech used in classrooms. To compensate for language difficulties, they tend to spend long hours studying outside of class time which leads to limiting the amount of time they have available to develop their oral and interactive language skills (Ballard \& Clanchy, 1997). This paper is an attempt to address the language-related needs of Saudi fellowship doctors and students of medical majors.

Needs analysis, sometimes introduced as needs assessment, plays a vital role in designing and carrying out any course or program within the field of English for Specific Purposes (ESP) (Munby, 1981; West, 1994.). This process involves systematic procedures for determining and addressing needs, or gaps between current conditions of a community or other defined population of people and desired conditions or wants. The discrepancy between the current condition and wanted condition must be measured accurately to identify the need clearly, whether that need is a desire to improve current situation or to correct a deficiency (Basturkmen, 2010). However, needs analysis should not only be implemented as a pre-stage process only to assess students' needs and design language courses. Needs analysis should be an 'on-going process' utilized in evaluating and improving language programs (White, 1998). Any process of needs analysis should take into account students' target needs and learning needs. Target needs involve what learners need to do in the target situation - i.e. language use, while learning needs refer to what learners need to do in order to learn i.e. language learning. A balanced focus on these two types of needs is necessary to achieve the desired influence not only the content of the language course but also what potential can be exploited through such course (Hutchinson $\&$ Waters, 1992).

\section{The study}

The purpose of this study is to investigate the English language needs of Saudi fellowship doctors and students of medical majors who are enrolled at medical and training programs in Australian hospitals and universities. Previous studies asserted that learners of English can benefit from needs analysis studies (Alharby, 2005; Károly, 2011). However, there are not many studies in the literature that investigated Saudi medical students' needs. This problem is common in the EFL context in the Arab world where the needs and perceptions of learners of English as a foreign language are not explored often and receive only little attention from researchers and language teaching professionals (Alqurashi, 2011; Kandil, 2002). The current study is expected to fill the gap and shed light on the views of Saudi 
medical students with respect to their needs in learning English for medical purposes. The results and recommendations of this study will contribute to explore their views of medical students regarding their target language needs and to draw conclusions based on their perceptions which provides curriculum developers with the necessary ideas in course design and material selection.

\section{Methods and Procedures}

The current study surveyed Saudi fellowship doctors and students of medical majors about their English language needs. The participants were sponsored by the ministry of Health, the ministry of Education, or different hospitals and enrolled at medical and training programs in Australian hospitals and universities. They cover a wide range of medical majors such as medicine, paramedics, nursing, radiology, medical laboratories, and pharmacy. The language needs of this group of participants were assessed through a questionnaire. Most of the previous studies which assessed the language needs of students who study English for specific purposes depended on questionnaires as an instrument for collecting data. This method of data gathering is the most common method used for collecting research data as it constitutes the basis of every survey-based statistical measurement (Brancato et al, 2006). Questionnaires are usually viewed as a more objective research tool that can provide a great deal of information in an economical form and produce generalizable results in a highly concrete and specific way because of large sample sizes (Giesen et al., 2010). The questionnaire used in this study was derived from a previous study by Hutchinson and Waters (1992). The questionnaire was sent to the participants via email in order to explore their views regarding their target language needs. A copy of the questionnaire is provided in the Appendix. The participants responded to the following two research questions:

- How frequently do you use the following English language skills?

- How important are the following English language skills to you?

English language skills were divided into four categories in the questionnaire:

A- Reading sub-skills:

1) Reading textbooks

2) Reading technical articles in journals

3) Reading technical manuals

4) Reading course handouts

5) Reading texts on the computer

6) Reading instructions for assignments/projects

7) Reading instructions for labs

8) Reading study notes

B- Writing sub-skills:

9) Writing lab reports

10) Writing assignments

11) Writing field-trip reports

12) Writing short projects

13) Taking notes in lectures

14) Writing test/exam answers

C- Listening sub-skills:

15) Following lectures

16) Following question/answer sessions in class

17) Listening to spoken presentations

18) Listening to instructions and explanations in labs

19) Listening to instructions for assignments

D- Speaking sub-skills:

20) Participating in discussions

21) Asking questions in class

22) Giving spoken presentations 


\section{Results and discussion}

Data derived from the questionnaire were entered into Statistical Package for the Social Sciences (SPSS), version 16, a software package used for statistical analysis, to obtain descriptive statistics. The percentages and frequencies of 156 participants' responses are presented in tables (below) to show the patterns of their preferences.

\subsection{Frequency of reading sub-skills}

As illustrated in Table 1, the responses to the first part related to reading sub-skills showed that most participants utilized high frequency in using English in different reading skills. The highest frequently used sub-skill was 'Reading instructions for assignments/ projects.' 125 of the responses $(80.1 \%)$ indicated that they always use English for this skill which demonstrates that students make efforts to comprehend reading assignments and understand concepts covered in class. Only 12 respondents (7.7\%) mentioned they rarely use English for that purpose. It is expected that students attach high significance to instructions related to the assignments and projects required in their programs. The lowest frequently used reading sub-skill was 'Reading technical manuals' where only 48 students indicated that they always use English for this skill. In return, 61 respondents (39.1\%) pointed out that they rarely utilized that sub-skill. This is maybe because students find reading manuals boring and full of technical terms that they are not familiar with or comprehend.

Table 1. How frequently do you use the following English language skills (Reading sub-skills)? $(\mathrm{N}=156)$

\begin{tabular}{lllllll}
\hline Questionnaire item & Always & $\%$ & Frequently & $\%$ & Rarely & $\%$ \\
\hline 1) Reading textbooks & 73 & 46.8 & 67 & 42.9 & 16 & 10.3 \\
\hline 2) Reading technical articles in journals & 82 & 52.6 & 56 & 35.9 & 18 & 11.5 \\
\hline 3) Reading technical manuals & 48 & 30.8 & 47 & 30.1 & 61 & 39.1 \\
\hline 4) Reading course handouts & 80 & 51.3 & 45 & 28.8 & 31 & 19.9 \\
\hline 5) Reading texts on the computer & 112 & 71.8 & 38 & 24.4 & 6 & 3.8 \\
\hline 6) Reading instructions for assignments/ projects & 125 & 80.1 & 19 & 12.2 & 12 & 7.7 \\
\hline 7) Reading instructions for labs & 100 & 64.1 & 31 & 19.9 & 25 & 16.0 \\
\hline 8) Reading study notes & 98 & 62.8 & 40 & 25.6 & 18 & 11.5 \\
\hline
\end{tabular}

\subsection{Frequency of writing sub-skills}

Table 2 illustrates participants' responses to the second part related to writing sub-skills and showed that 125 respondents, more than three fourths, used English in writing assignments. This is an expected feedback since they have to turn in assignments very frequently during their study time. This high number of positive responses reveals that the students found writing a flexible means of demonstrating learning as well as a method of exploring one's thinking to stimulate learning (Alqurashi, 2014; Gordon, 2008). Previous studies found that writing assignments help students practice communication skills such as paraphrasing, summarizing, comparing, describing, and expressing observations (Pillai, 2014).

The lowest frequently used writing skill was 'Writing field-trip reports.' Only 52 (33.3\%) respondents indicated that they always use this skill while 56 (35.9\%) others mentioned they rarely use English for this skill. Field trip reports are among the key research skills that usually students at graduate level have to master. In such reports, student researchers documented a highly organized account of their experience using outlines to express the main points of the trip. There are different formats of field reports depending on the discipline. However, all types of field trip formats should identify the main issue, give notes in the field, analyze and discuss data and present conclusions and recommendations (Burgess, 2002). It seems that the majority of the respondents were college students and not required to do field trips and consequently they did not turn in field trip reports.

Table 2. How frequently do you use the following English language skills (Writing sub-skills)? $(\mathrm{N}=156)$

\begin{tabular}{lllllll}
\hline Questionnaire item & Always & $\%$ & Frequently & $\%$ & Rarely & $\%$ \\
\hline 9) Writing lab reports & 92 & 59.0 & 33 & 21.2 & 31 & 19.9 \\
\hline 10) Writing assignments & 125 & 80.1 & 16 & 10.3 & 15 & 9.6 \\
\hline 11) Writing field-trip reports & 52 & 33.3 & 48 & 30.8 & 56 & 35.9 \\
\hline 12) Writing short projects & 69 & 44.2 & 63 & 40.4 & 24 & 15.4 \\
\hline 13) Taking notes in lectures & 82 & 52.6 & 50 & 32.1 & 24 & 15.4 \\
\hline 14) Writing test/exam answers & 107 & 68.6 & 29 & 18.6 & 20 & 12.8 \\
\hline
\end{tabular}

\subsection{Frequency of listening sub-skills}

Participants' responses to the third part related to listening sub-skills are depicted in table 3 . The highest frequently used listening sub-skill was 'Listening to instructions for assignments' where $128(82.1 \%)$ participants indicated that they 
used English for that sub-skill. It is evident that participants consider assignments challenging tasks that have great impact on their performance which, according to some studies, makes them more focused and highly aware of the context, content, and charge involved in an assignment and how that can improve their achievement (Mitchell, 1996). The participants pointed out in their responses that they use English for other listening sub-skill quite frequently. 'Listening to instructions and explanations in labs' was the lowest frequently used listening sub-skill with 94 $(60.3 \%)$ respondents used this skill always and 45 (28.8\%) respondents used it frequently. Only $17(10.9 \%)$ respondents indicated that they rarely used English for this sub-skill which indicates that they are at early stages of their study programs where they are not required to attend labs.

Table 3. How frequently do you use the following English language skills (Listening sub-skills)? $(\mathrm{N}=156)$

\begin{tabular}{|c|c|c|c|c|c|c|}
\hline Questionnaire item & Always & $\%$ & Frequently & $\%$ & Rarely & $\%$ \\
\hline 15) Following lectures & 113 & 72.4 & 34 & 21.8 & 9 & 5.8 \\
\hline $\begin{array}{l}\text { 16) Following question/answer sessions in } \\
\text { class }\end{array}$ & 99 & 63.5 & 42 & 26.9 & 15 & 9.6 \\
\hline 17) Listening to spoken presentations & 118 & 75.6 & 33 & 21.2 & 5 & 3.2 \\
\hline $\begin{array}{l}\text { 18) Listening to instructions and } \\
\text { explanations in labs }\end{array}$ & 94 & 60.3 & 45 & 28.8 & 17 & 10.9 \\
\hline $\begin{array}{l}\text { 19) Listening to instructions for } \\
\text { assignments }\end{array}$ & 128 & 82.1 & 16 & 10.3 & 12 & 7.7 \\
\hline
\end{tabular}

\subsection{Frequency of speaking sub-skills}

Table 4 illustrates participants' responses to the fourth part of the questionnaire related to speaking sub-skills. This part includes only three skills; two of them, 'Participating in discussions' and 'Giving spoken presentations' were used frequently. In particular, more than half of the sample population, 81 (51.9\%) and 87 (55.8\%) respectively, mentioned they always used English for those skills. The two sub-skills are key classroom activities that students need to practice in order to enhance their understanding and progress that contribute to final assessment. Such skills can identify areas for improvement and promote effective and constructive progress to higher levels of student achievement and greater equity of student outcomes (Monsen, 2002). The third speaking skill, 'Asking questions in class' were used less frequently. Only 60 respondents pointed out they always used English to ask questions in class and 33 (21.2\%) rarely used English for that purpose. Usually new students hesitate to ask questions because of many reasons; they do not have enough competence to deliver a question, or because of their anticipation of a negative reaction related to teacher cooperativeness, and in less cases because they wanted to reach answers on their own (Wu, 1993).

Table 4. How frequently do you use the following English language skills (Speaking sub-skills)? $(\mathrm{N}=156)$

\begin{tabular}{lllllll}
\hline Questionnaire item & Always & $\%$ & Frequently & $\%$ & Rarely & $\%$ \\
\hline 20) Participating in discussions & 81 & 51.9 & 58 & 37.2 & 17 & 10.9 \\
\hline 21) Asking questions in class & 60 & 38.5 & 63 & 40.4 & 33 & 21.2 \\
\hline 22) Giving spoken presentations & 87 & 55.8 & 40 & 25.6 & 29 & 18.6 \\
\hline
\end{tabular}

\subsection{Importance of reading sub-skills}

The following parts list and discuss participants' responses to the second question of the questionnaire related to the importance of the four language skills. Responses to items 1-8 of the second part, related to the importance of reading sub-skills, showed the perspectives of the respondents on how important those skills were to them. $132(84.6 \%)$ of the respondents rated 'Reading instructions for assignments/projects' as very important and only 2 (1.3\%) respondents pointed out that this language sub-skill is not important. This result is expected since, according to participants' responses, 'Reading instructions for assignments/ projects' was the highest frequently used reading sub-skill. Learners usually attach high importance to any skills that they use frequently to help them get specific information from the reading texts and achieve the utmost aim of improving reading abilities (Pan, 2009). The only reading sub-skill that respondents rated far less important than other sub-skills was the 'Reading technical manuals.' Again, this is an echo to how frequently the respondents used it. 'Reading technical manuals' was perceived very important by only 54 (34.6\%) participants, moderately important by $63(40.4 \%)$ participants, and not important by 39 (25.0\%) participants. It seems that most respondents try to avoid reading technical manuals as they found it boring, unnecessary, and full of extra information that did not contribute to improving their overall reading skills. 
Table 5. How important are the following English language skills to you (Reading sub-skills)? $(\mathrm{N}=156)$

\begin{tabular}{lllllll}
\hline Questionnaire item & $\begin{array}{l}\text { Very } \\
\text { important }\end{array}$ & $\%$ & $\begin{array}{l}\text { Moderately } \\
\text { important }\end{array}$ & $\%$ & $\begin{array}{l}\text { Not } \\
\text { important }\end{array}$ & $\%$ \\
\hline 1) Reading textbooks & 124 & 79.5 & 28 & 17.9 & 4 & 2.6 \\
\hline 2) Reading technical articles in journals & 100 & 64.1 & 53 & 34.0 & 3 & 1.9 \\
\hline 3) Reading technical manuals & 54 & 34.6 & 63 & 40.4 & 39 & 25.0 \\
\hline 4) Reading course handouts & 113 & 72.4 & 27 & 17.3 & 16 & 10.3 \\
\hline 5) Reading texts on the computer & 97 & 62.2 & 50 & 32.1 & 9 & 5.8 \\
\hline $\begin{array}{l}\text { 6) Reading instructions for assignments/ } \\
\text { projects }\end{array}$ & 132 & 84.6 & 22 & 14.1 & 2 & 1.3 \\
\hline 7) Reading instructions for labs & 107 & 68.6 & 39 & 25.0 & 10 & 6.4 \\
\hline 8) Reading study notes & 116 & 74.4 & 37 & 23.7 & 3 & 1.9 \\
\hline
\end{tabular}

\subsection{Importance of writing sub-skills}

Participants' views of the importance of writing sub-skills are highlighted in table 6. The most important writing subskill for the participants was 'Writing assignments.' $136(87.2 \%)$ respondents rated this sub-skill as very important while only $3(1.9 \%)$ respondents rated it as not important. This result goes hand in hand with participants' feedback about the frequency of using writing sub-skills when more than two thirds of sample population indicated that the highest frequently used writing sub-skills was 'Writing assignments.' That means the participants gained a high level of confidence when writing assignments through the medium of English and satisfied the minimum requirements of academic writing, particularly style, grammar, and cohesion (Crusan, 2002). The least important writing sub-skill according to the participants' responses was 'Writing field-trip reports' which also was the least frequently used writing sub-skill. Only 56 (35.9\%) participants indicated that 'Writing field-trip reports' is very important, 61 (39.1\%) pointed out that it is moderately important, and 39 (25.0\%) revealed it is not important. This high number of students who do not consider writing field trip reports very important could be bachelor students who are not required to do field trips or write this kind of reports.

Table 6. How important are these English language skills to you (Writing sub-skills)? $(\mathrm{N}=156)$

\begin{tabular}{lllllll}
\hline Questionnaire item & $\begin{array}{l}\text { Very } \\
\text { important }\end{array}$ & $\%$ & $\begin{array}{l}\text { Moderately } \\
\text { important }\end{array}$ & $\%$ & $\begin{array}{l}\text { Not } \\
\text { important }\end{array}$ & $\%$ \\
\hline 9) Writing lab reports & 95 & 60.9 & 53 & 34.0 & 8 & 5.1 \\
\hline 10) Writing assignments & 136 & 87.2 & 17 & 10.9 & 3 & 1.9 \\
\hline 11) Writing field-trip reports & 56 & 35.9 & 61 & 39.1 & 39 & 25.0 \\
\hline 12) Writing short projects & 85 & 54.5 & 52 & 33.3 & 19 & 12.2 \\
\hline 13) Taking notes in lectures & 97 & 62.2 & 45 & 28.8 & 14 & 9.0 \\
\hline 14) Writing test/exam answers & 111 & 71.2 & 29 & 18.6 & 16 & 10.3 \\
\hline
\end{tabular}

\subsection{Importance of listening sub-skills}

Table 7 shows the respondents' perspectives of the importance of listening sub-skills. 'Listening to instructions for assignments' was perceived very important by 125 (80.1\%) participants, moderately important by 31 (19.9\%) participants, and was not rated as not important by any participant. Again, this is the same listening sub-skill that the participants used highly more frequently than other listening sub-skills. It seems that the participants became familiar with the educational environment in Australian universities that depends on assignments as a major assessment indicator. To understand assignment instructions students, in many cases, promote dialogue with teachers about the scope of the assignment, the nature of resources they need, and any knowledge or experience related to the topic of the assignment (Masters, 2013). In addition, assignments push students to develop different study skills such managing study time, taking notes, planning assignments, revising for exams and preparing presentations as well as various social skills like interacting with peers to extend their learning which enhances their social engagement and foster their sustainable learning (Singh \& Terry, 2008). 


\begin{tabular}{|c|c|c|c|c|c|c|}
\hline Questionnaire item & $\begin{array}{l}\text { Very } \\
\text { important }\end{array}$ & $\%$ & $\begin{array}{l}\text { Moderately } \\
\text { important }\end{array}$ & $\%$ & $\begin{array}{l}\text { Not } \\
\text { important }\end{array}$ & $\%$ \\
\hline 15) Following lectures & 106 & 67.9 & 39 & 25.0 & 11 & 7.1 \\
\hline $\begin{array}{l}\text { 16) Following question/answer } \\
\text { sessions in class }\end{array}$ & 110 & 70.5 & 41 & 26.3 & 5 & 3.2 \\
\hline 17) Listening to spoken presentations & 97 & 62.2 & 47 & 30.1 & 12 & 7.7 \\
\hline $\begin{array}{l}\text { 18) Listening to instructions and } \\
\text { explanations in labs }\end{array}$ & 106 & 67.9 & 42 & 26.9 & 8 & 5.1 \\
\hline $\begin{array}{l}\text { 19) Listening to instructions for } \\
\text { assignments }\end{array}$ & 125 & 80.1 & 31 & 19.9 & -- & -- \\
\hline
\end{tabular}

\subsection{Importance of speaking sub-skills}

The responses illustrated in Table 8 show that the participants attached relative importance to the three speaking subskills. The number of respondents who rated the three sub-skills as very important were $92-99(59.0 \%-63.5 \%)$ while less than $1 / 8^{\text {th }}$ of the participants perceived these sub-skills as not important. Learners utilized the three speaking subskills in classrooms as they are engaged in active learning practices and most teachers stated clearly in class syllabus that classroom activities count as part of the final grade. Moreover, group learning techniques provided equal opportunities to all learners to engage in classroom activities where they are encouraged to participate in discussions, ask questions, and give spoken presentations (Röver, 2014).

Table 8. How important are these English language skills to you (Speaking sub-skills)? $(\mathrm{N}=156)$

\begin{tabular}{lllllll}
\hline Questionnaire item & $\begin{array}{l}\text { Very } \\
\text { important }\end{array}$ & $\%$ & $\begin{array}{l}\text { Moderately } \\
\text { important }\end{array}$ & $\%$ & $\begin{array}{l}\text { Not } \\
\text { important }\end{array}$ & $\%$ \\
\hline 20) Participating in discussions & 96 & 61.5 & 54 & 34.6 & 6 & 3.8 \\
\hline 21) Asking questions in class & 99 & 63.5 & 43 & 27.6 & 14 & 9.0 \\
\hline 22) Giving spoken presentations & 92 & 59.0 & 45 & 28.8 & 19 & 12.2 \\
\hline
\end{tabular}

\section{Conclusion and recommendations}

This paper explored the perceptions of 156 Saudi fellowship doctors and medical students attending different hospitals and universities in Australia about how frequently they use different English Language skills and how important they think these skills were. In general, responses to the questionnaire showed that almost all English language sub-skills were used highly frequently and rated important. In addition, results revealed high conformity between the sub-skills that the participants used most frequently and those that they perceived very important. These sub-skills were reading instructions for assignments/projects, writing assignments, listening to instructions for assignments, and participating in discussions which indicate high awareness of the importance of different English language skills that learners have to know in order to function effectively in the target situation. These results are consistent with those of some previous studies that emphasized the significant role of English as a lingua franca in scientific fields (Hui, 2007) and found that English learning seems to be more important for the students as prospective medical doctors (Kayaoğlu \& Akbaş, 2016).

Since English is the academic and professional vehicle of communication in classrooms, labs, library, doctors and students of medical majors need to develop certain English language skills to carry out the necessary duties and responsibilities in the medical field upon their return where they are cross-trained in report writing, verbal presentation, and multiple administrative aspects. It is clear from the participants' responses that they want to master those English language skills in order to enhance their communication skills and maximize their opportunities to secure a job in the competitive employment market in Saudi Arabia (Al-Mously et al., 2013). Moreover, competence in the English language has become a decisive factor in the medical field especially in the management team where being able to communicate proficiently in English is important for promotion and holding higher positions. Effective competence in the English language is also necessary to execute one's duties successfully especially in this era of globalization where English language and borderless labour market force work hand-in-hand (Alharby, 2005).

This study aimed at identifying the particular academic and communicative needs that this particular group of learners were expected to participate in as users of the target language. Identifying such needs is, by all means, an integral part of decision making processes in the field of teaching English for specific purposes where it is necessary to find out what is specifically applicable and appropriate for the target situation and target language learners in terms of their needs. We can conclude there is a critical need to restructure English for medical purposes programs in Saudi Arabia to make course design, content, and materials responsive to target language learners' own future agenda. Depending heavily on medical English textbooks might not be enough for medical students studying in an EFL (English as a Foreign 
Language) context since most of the medical English textbooks used are mostly addressing the needs of students in ESL (English as a Second Language) contexts.

Participants' responses in this study suggested that college English language courses for medical majors need to focus more on language-related aspects like fluency, understanding, accuracy, and structure to prepare doctors and medical professionals for working in medical jobs that depend on heavy usage of the English language. Dealing with people's health requires high English language proficiency to ensure understanding the nature of medicine and diseases, conducting the necessary procedures, giving the correct instructions, and responding to different medical conditions. Therefore, there should be more institutional language-related training because medical information tends to be presented and published internationally in English. In addition, college English language courses should focus on improving communicative competence aspects to ensure smooth cultural interaction with co-workers from all around the world. Cultural interaction is important to be considered when designing a curriculum to prepare students for their future careers since working environment in health institutions in Saudi Arabia represents many multicultural as well as multilingual situations with foreign co-workers.

\section{References}

Alharbi, M. (2005). ESP target situation needs analysis: The English language communicative needs as perceived by the health professionals in the Riyadh area. Unpublished PhD dissertation, Athens: The University of Georgia.

Al-Hazimi, A., Zaini, R., Al-Hyiani, A., Hassan, N., Gunaid, A., \& Ponnamperuma, G. (2004). Educational environment in traditional and innovative medical schools: A study in four undergraduate medical schools. Education for Health-Abingdon-Carfax Publishing Limited, 17(2), 192-203. Retrieved from http://www.kau.edu.sa/Files/0003490/Researches/22028_Educational\%20Enviroment.pdf

Al-Kabbaa, A. F., Ahmad, H, H., Saeed, A. A., Abdalla, A. M., \& Mustafa, A. A. (2012). Perception of the learning environment by students in a new medical school in Saudi Arabia: Areas of concern. Journal of Taibah University Medical Sciences, 7(2), 69-75.

Amed, J. (2011). Acculturation and Academic Phenomenon of Saudi Arabian Scholarship students entering Medical and Health Education. Unpublished PhD Thesis. Sydney: The University of Sydney. Faculty of Medicine.Al-Mously, N., Salem, R. \& Al-Hamdan, N. (2013). The impact of gender and English language on the academic performance of students: An experience from new Saudi medical school. Journal of Contemporary Medical Education, 1(3), $170-176$.

Alqurashi, F. (2011). Teaching English for police purposes in Saudi Arabia: An exploratory study. Journal of Language Teaching and Research, 2(4), 844-849. Retrieved from http://dx.doi.org/10.4304/j1tr.2.4.844-849

Alqurashi, F. (2014). The Effects of Motivation on EFL College Students' Achievement. Studies in English Language Teaching, 2(4), 385-400. Retrieved from http://www.scholink.org/ojs/index.php/selt/article/view/265

Antic, Z. (2007). Forward in Teaching English for Medical Purposes. FACTA UNIVERSITATIS Series: Medicine and Biology, 14(3), 141-147. Retrieved from http://facta.junis.ni.ac.rs/mab/mab200703/mab200703-08.pdf

Ballard, B. \& Clanchy, J. (1997). Teaching international students: a brief guide for lecturers and supervisors. Deakin: IDP Education Australia.

Barron, P.E. (2004). An evaluation of learning styles, learning issues and learning problems of Confucian heritage culture students studying hospitality and tourism management in Australia. Unpublished PhD Thesis. Brisbane: The University of Queensland, Australia.

Basturkmen , H. (2010). Developing Courses in English for Specific Purposes. London: Palgrave Macmillan.

Brancato, G., Macchia, S., Murgia, M., Signore, M., Simeoni, G., Blanke, K., Körner, T., Nimmergut, A., Lima, P., Paulino, R., \& Hoffmeyer-Zlotnik, J. (2006). Handbook of Recommended Practices for Questionnaire Development and Testing in the European Statistical System. European Commission Grant Agreement 2004103000002. Retrieved from http://www.istat.it/en/files/2013/12/Handbook_questionnaire_development_2006.pdf

Burgess, R. G. (2002). In the field: An introduction to field research. Routledge.

Crusan, D. (2002). An assessment of ESL writing placement assessment. Assessing Writing, 8(1), 17-30.

Dudley-Evans, T. (1998). Developments in English for Specific Purposes: A multi-disciplinary approach. Cambridge: Cambridge University Press.

Gatehouse, K. (2001). Key issues in English for specific purposes (ESP) curriculum development. The Internet TESL Journal. Retrieved from http://iteslj.org/Articles/GatehouseESP.html

Giesen, D., Meertens, V., Vis-Visschers, R., \& Beukenhorst, D. (2010). Methods Series: Theme: Questionnaire development. Statistics Netherlands. Retrieved from http:/www.cbs.nl/NR/rdonlyres/99B7482F-E09E-4D86-90A1666DC42745BD/0/2012Questionairedevelopmentart.pdf

Gordon, L. (2008). Writing and good language learners. In C. Griffiths (Ed.), Lessons from good language learners (pp. 244-254). Cambridge: Cambridge University Press.

Hui, Z. (2007). Teaching technical English to engineering students. Sino-US English Teaching, 4(9), 54-57. Retrieved from http://www.linguist.org.cn/doc/su200709/su20070910.pdf 
Hutchinson, T. \& Waters, A. (1992). English for Specific Purposes: A Learning centred approach. Cambridge: Cambridge University Press.

Kaliyadan, F., Thalamkandathil, N., Parupalli, S., Amin, T., Balaha, M., \& Ali, W. (2015). English language proficiency and academic performance: A study of a medical preparatory year program in Saudi Arabia. Avicenna Journal of Medicine, 5(4), 140-144. Retrieved from http://www.avicennajmed.com/article.asp?issn=22310770; year $=2015$; volume $=5$;issue $=4$; spage $=140$; epage $=144$; aulast $=$ Kaliyadan

Kandil, A. (2002). Needs analysis and the Arab learners. TESOL Arabia, 10 (2), 10-17. Retrieved from http://ilearn.20m.com/articlesactr.html\#ahmad.

Lili, Z. (2015). Developing ESP Instruction in Context-specific Way: Needs Analysis and Strategies Design. International Journal of Engineering and Industries (IJEI), 6(1), 63-68.

Károly. A.( 2011). Exploring learners' needs and expectations: translating EU texts in an English bachelor's programme at a Hungarian college. WoPaLP , 6, 58-85. Retrieved from http://langped.elte.hu/WoPaLParticles/W5Karoly.pdf

Kayaoğlu, M. N. \& Akbaş, R. D. (2016). An Investigation into Medical Students' English Language Needs. Participatory Educational Research (PER) Special Issue - January, 63-71. Retrieved from http://dx.doi.org/10.17275/per.16.spi.1.8

Masters, G. (2013). Reforming educational assessment: imperatives, principles, and challenges. Melbourne: Australian Council for $\quad$ Educational Research. $\quad$ Retrieved from http://research.acer.edu.au/cgi/viewcontent.cgi?article=1021\&context=aer

Mitchell, R. (1996). Front-end Alignment: Using Standards to Steer Educational Change, a Manual for Developing Standards. Washington, D.C.: Education Trust.

Monsen, L. I. (2002). School-based Evaluation in Norway: Why is it so Difficult to Convince Teachers of its Usefulness? School-based Evaluation: An International Perspective, JAI Press, Oxford, 73-88.

Munby, J. (1981). Communicative syllabus design: A sociolinguistic model for designing the content of purpose-specific language programmes. Cambridge: Cambridge University Press.

Orr, T. (2005). Professional standards in English for Specific purpose. OnCUE, 13(1), 9-16.

Pan, L. (2009). Sub-skills Approach and Extensive Approach to Reading in TEFL. Journal of Cambridge Studies, 4 (3), 112-120. Retrieved from http://dx.doi.org/10.17863/CAM.1609

Pillai, A. (2014). Task requirements and students' perceptions of prompts in an academic writing classroom. Malaysian Journal of ELT Research, 10(2), 82-106.

Porcaro, J. W. (2013). Teaching English for science and technology: An approach for reading with engineering English. English Teaching Forum, 51(2), 32-39. $\quad$ Retrieved http://americanenglish.state.gov/files/ae/resource_files/51_2_6_porcaro.pdf

Robinson, P. (1991). ESP today: A practitioner's guide. New York: Prentice Hall.

Robson, M. (2014). The English Effect. Retrieved from https://www.britishcouncil.org/sites/default/files/english-effectreport-v2.pdf

Röver, C. (2014). Testing ESL pragmatics. Frankfurt: Peter Lang.

Singh, K. \& Terry, J. (2008, November). Fostering students' self-assessment skills for sustainable learning. Proceedings of the EDU-COM International Conference. Khon Kaen, Thailand. Retrieved from http://ro.ecu.edu.au/cgi/viewcontent.cgi?article=1038\&context=ceducom

Skelton, J. R. \& Whetstone, J. (2012). English for Medical Purposes and Academic Medicine: looking for common ground. Ibérica, Journal of the European Association of Languages for Specific Purposes, 24, 87-102.

Taylor, C. \& Albasri, W. (2014). The Impact of Saudi Arabia King Abdullah's Scholarship Program in the U.S. Open Journal of Social Sciences, 2(10), 109-118.

West, R. (1994). Needs analysis in language teaching. Language teaching, 27, 1-19.

White, R. V. (1998). The ELT Curriculum. Cambridge: Basil Blackwell.

Wu, K. Y. (1993). Classroom interaction and teacher questions revisited. RELC journal, 24(2), 49-68. 
Appendix

How frequently do you use the following English language skills?

\begin{tabular}{|c|c|c|c|c|}
\hline & English language skills & Always & Frequently & Rarely \\
\hline \multirow{8}{*}{$\begin{array}{l}\text { Reading } \\
\text { sub-skills }\end{array}$} & 1) Reading textbooks & & & \\
\hline & 2) Reading technical articles in journals & & & \\
\hline & 3) Reading technical manuals & & & \\
\hline & 4) Reading course handouts & & & \\
\hline & 5) Reading texts on the computer & & & \\
\hline & 6) Reading instructions for assignments/projects & & & \\
\hline & 7) Reading instructions for labs & & & \\
\hline & 8) Reading study notes & & & \\
\hline \multirow{6}{*}{$\begin{array}{l}\text { Writing } \\
\text { sub-skills }\end{array}$} & 9) Writing lab reports & & & \\
\hline & 10) Writing assignments & & & \\
\hline & 11) Writing field-trip reports & & & \\
\hline & 12) Writing short projects & & & \\
\hline & 13) Taking notes in lectures. & & & \\
\hline & 14) Writing test/exam answers & & & \\
\hline \multirow{5}{*}{$\begin{array}{l}\text { Listening } \\
\text { sub-skills }\end{array}$} & 15) Following lectures & & & \\
\hline & 16) Following question/answer sessions in class & & & \\
\hline & 17) Listening to spoken presentations & & & \\
\hline & $\begin{array}{l}\text { 18) Listening to instructions and explanations in } \\
\text { labs }\end{array}$ & & & \\
\hline & 19) Listening to instructions for assignments & & & \\
\hline \multirow{4}{*}{$\begin{array}{l}\text { Speaking } \\
\text { sub-skills }\end{array}$} & 20) Participating in discussions & & & \\
\hline & 21) Asking questions in class & & & \\
\hline & 22) Giving spoken presentations & & & \\
\hline & 23) Others (please specify) & & & \\
\hline
\end{tabular}

2. How important are the following English language skills to you?

\begin{tabular}{|c|c|c|c|c|}
\hline & English language skills & $\begin{array}{l}\text { Very } \\
\text { important }\end{array}$ & $\begin{array}{l}\text { Moderately } \\
\text { important }\end{array}$ & $\begin{array}{l}\text { Not } \\
\text { important }\end{array}$ \\
\hline \multirow{8}{*}{$\begin{array}{l}\text { Reading } \\
\text { sub-skills }\end{array}$} & 1) Reading textbooks & & & \\
\hline & 2) Reading technical articles in journals & & & \\
\hline & 3) Reading technical manuals & & & \\
\hline & 4) Reading course handouts & & & \\
\hline & 5) Reading texts on the computer & & & \\
\hline & 6) Reading instructions for assignments/projects & & & \\
\hline & 7) Reading instructions for labs & & & \\
\hline & 8) Reading study notes & & & \\
\hline \multirow{6}{*}{$\begin{array}{l}\text { Writing } \\
\text { sub-skills }\end{array}$} & 9) Writing lab reports & & & \\
\hline & 10) Writing assignments & & & \\
\hline & 11) Writing field-trip reports & & & \\
\hline & 12) Writing short projects & & & \\
\hline & 13) Taking notes in lectures. & & & \\
\hline & 14) Writing test/exam answers & & & \\
\hline \multirow{5}{*}{$\begin{array}{l}\text { Listening } \\
\text { sub-skills }\end{array}$} & 15) Following lectures & & & \\
\hline & 16) Following question/answer sessions in class & & & \\
\hline & 17) Listening to spoken presentations & & & \\
\hline & $\begin{array}{l}\text { 18) Listening to instructions and explanations in } \\
\text { labs }\end{array}$ & & & \\
\hline & 19) Listening to instructions for assignments & & & \\
\hline \multirow{4}{*}{$\begin{array}{l}\text { Speaking } \\
\text { sub-skills }\end{array}$} & 20) Participating in discussions & & & \\
\hline & 21) Asking questions in class & & & \\
\hline & 22) Giving spoken presentations & & & \\
\hline & 23) Others (please specify) & & & \\
\hline
\end{tabular}

